\title{
Postharvest Application of Calcium and Magnesium to Honeydew and Netted Muskmelons: Effects on Tissue Ion Concentrations, Quality, and Senescence
}

\author{
Gene E. Lester ${ }^{1}$ \\ U.S. Department of Agriculture, Agricultural Research Service, Kika de la Garza, SubtropicalAgricultural \\ Research Center, 2301 South International Boulevard, Weslaco, TX 78596 \\ Michael A. Grusak ${ }^{2}$ \\ U.S. Department of Agriculture, Agricultural Research Service, Children's Nutrition Research Center, \\ Department of Pediatrics, Baylor College of Medicine, 1100 Bates Street, Houston, TX 77030
}

AdDITIONAL INDEX wORDs. Cucumis melo, Inodorus Group, Reticulatus Group, disease, firmness, histology, plasma membrane

\begin{abstract}
Aвstract. Muskmelon senescence is directly associated with a decline in hypodermal mesocarp membrane integrity and its Ca concentration, but infusing $\mathrm{Ca}$ into melons has been a problem. Fully ripened and abscised hybrid honeydew [Cucumis melo L. (Inodorus Group) 'Honey Brew'] and netted muskmelon [Cucumis melo L. (Reticulatus Group) 'Explorer'] fruit were submerged (dipped) $20 \mathrm{~min}$ at $25 \pm 3{ }^{\circ} \mathrm{C}$ in a solution containing a Ca-chelate, a Mg-chelate, a combination of both chelates, or no mineral chelate. Following 10 or 24 days of cold storage ( $4{ }^{\circ} \mathrm{C}$ for 'Explorer' and 10 ${ }^{\circ} \mathrm{C}$ for 'Honey Brew'), fruit were analyzed for mineral content and various senescence-related parameters. Abscised 'Honey Brew' fruit dipped in either Ca-chelate or (Ca+Mg)-chelate and abscised 'Explorer' fruit dipped in (Ca+Mg)-


Maintaining hypodermal mesocarp tissue Ca concentrations at this level during postharvest storage, especially for fully ripe 'Honey Brew' fruit, maintained membrane integrity and fruit firmness, and extended storage life 2.4 -fold (i.e., to 24 days). The senescence regulatory effect of postharvest Ca-chelate treatments on abscised 'Explorer' was highly variable, compared to 'Honey Brew', which appeared to be due to the surface netting interfering with movement of Ca into the hypodermal mesocarp. Thus, postharvest Ca-chelate application to abscised 'Honey Brew' fruit could delay fruit senescence in commercial storage, and open up new markets for fully ripened honeydew melons.
\end{abstract}

Maintenance of cellular integrity in the hypodermal mesocarp tissue is critical for regulating postharvest senescence in fruit of netted muskmelon [Cucumis melo (Reticulatus Group)] and honeydew [Cucumis melo (Inodorus Group)] (Lester and Stein, 1993; Lester, 1998b). Cellular integrity is determined, in part, by tissue $\mathrm{Ca}$ levels; $\mathrm{Ca}$ is believed to be involved as an antiripening, antisenescence agent in fruit (Ferguson, 1984; Poovaiah et al., 1988), and as an ion necessary for cellular signal transduction (Poovaiah and Reddy, 1993).

Calcium concentration within the edible mesocarp of netted muskmelon remains constant or declines slightly throughout fruit growth and maturation (Bernadac et al., 1996). In the rind-associated hypodermal mesocarp tissue, in particular, $\mathrm{Ca}$ concentration increases throughout muskmelon development, then declines sharply following maturity and during postharvest senescence (Bernadac et al., 1996). Senescence can be delayed in netted muskmelon by incubating hypodermal mesocarp disks in isotonic $\mathrm{CaCl}_{2}$ solution, which retards plasma membrane lipid degradation and maintains osmotic tonicity of the cells (Lester, 1996).

If muskmelon $\mathrm{Ca}$ concentration could be increased in vivo, especially in the hypodermal mesocarp tissue, whole fruit post-

Received for publication 15 Dec. 1998. Accepted for publication 30 Apr. 1999 Aleena Tarshis Moreno is gratefully acknowledged for muskmelon production. This research was funded by the USDA-ARS under CRIS no. 6204-43000-00700D to G.E.L. and under cooperative agreement no. 58-6250-1-003 to M.A.G. Use of company or product names by the USDA does not imply approval or recommendation of the product to the exclusion of others that also may be suitable. The cost of publishing this paper was defrayed in part by the payment of page charges. Under postal regulations, this paper therefore must be hereby marked advertisement solely to indicate this fact.

'E-mail: glester@pop.tamu.edu.

2E-mail: mgrusak@bcm.tmc.edu. harvest senescence could be delayed. However, applications of Ca fertilizer to soil may be of questionable value. For example, $\mathrm{Ca}$ soil enrichments at the time of planting ( 280 to $1120 \mathrm{~kg} \cdot \mathrm{ha}^{-1}$ ) had no effect on $\mathrm{Ca}$ concentration in the rind tissue of watermelon [Citrullus lanatus (Thunb.) Matsum. \& Nak.] (Scott et al., 1993). Instead, supplemental Ca may need to be applied to the muskmelon surface. Recent studies on sour cherry (Prunus cerasus L.) (Anderson and Campbell, 1995); kiwifruit (Actinidia deliciosa C.S. Liang \& A.R. Ferguson) (Gerasopoulos et al., 1996); mushrooms (Agaricus bisporus L.) (Miklus and Beelman, 1996); and strawberries (Fragaria ×ananassa Duchesne) (Garcia et al., 1996), showed that applications of Ca immediately before, or just after harvest, maintained cell turgor, plasma membrane integrity, fruit firmness, and extended storage life.

The effectiveness of postharvest application of $\mathrm{Ca}$ to whole netted or honeydew muskmelons has not been reported. Therefore, the objectives of this study were first, to establish the developmental profile of $\mathrm{Ca}$ in honeydew mesocarp tissues during growth, maturation and postharvest senescence, for comparison with netted muskmelons (Bernadac et al., 1996). The second objective was to evaluate and contrast the tissue ion concentrations, surface characteristics, and mesocarp physicochemical characteristics of postharvest netted and honeydew muskmelons after exposure to $\mathrm{Ca}$ - and/or $\mathrm{Mg}$-chelate dip solutions, and following commercial storage for 10 or $24 \mathrm{~d}$.

\section{Materials and Methods}

Plant material. 'Honey Brew' hybrid honeydew (nonnetted, green-fleshed) and 'Explorer' hybrid (netted, orange-fleshed) muskmelon plants were grown in a greenhouse as described 
previously (Lester, 1998a). Flowers were hand-pollinated, and one fruit per plant was allowed to develop.

Chelate treatments. Fruit designated for postharvest dip treatments were harvested at abscission, just after sunrise, and were assayed immediately, or were submerged (dipped) for 20 min in one of the following solutions at the same temperatures as that of the harvested fruit: tap water, Ca-chelate $(0.08 \mathrm{M} \mathrm{Ca}-$ metalosate), $\mathrm{Mg}$-chelate ( $0.08 \mathrm{M} \mathrm{Mg-metalosate),} \mathrm{or} \mathrm{a} \mathrm{mixture} \mathrm{of}$ the Ca-chelate and the $\mathrm{Mg}$-chelate $(0.08 \mathrm{M} \mathrm{Ca}$-metalosate and 0.08 м Mg-metalosate), which will be referred to as ( $\mathrm{Ca}+\mathrm{Mg})$ chelate. These chelates are amino acid based and are proprietary formulations of Albion Laboratories, Clearfield, Utah. All chelate solutions were adjusted to $\mathrm{pH} 7$ with citric acid. Following the dip, all fruit were air dried for 20 min before commercial storage conditions $\left(4{ }^{\circ} \mathrm{C}\right.$ and $90 \% \pm 5 \%$ relative humidity $(\mathrm{RH})$ for 'Explorer' or $10^{\circ} \mathrm{C}$ and $90 \% \pm 5 \% \mathrm{RH}$ for 'Honey Brew') for 7 or $21 \mathrm{~d}$. All fruit were stored an additional $3 \mathrm{~d}$ at $21^{\circ} \mathrm{C}$ and $86 \%$ $\mathrm{RH}$ (10 d or $24 \mathrm{~d}$ total storage) before retrieval for various analyses.

Fruit SURFace CHARACTERISTiCs. Following storage, all fruit were rated for surface darkening, diseased areas, and stem-end mold, as described by Carter (1981) and Lester (1989). Data are presented as the percentage of all fruit affected within a treatment.

DETERMINATION OF FRUIT WEIGHT LOSS, FIRMNESS, AND ELECTROLYTE LEAKAGE. Weight loss was calculated as the percent difference in weight for each fruit from the day of harvest to 10 or $24 \mathrm{~d}$ storage. Firmness of whole-fruit equatorial hypodermal mesocarp tissue, less the epidermis, was measured using a $4.5 \mathrm{~cm}$ $\times 3 \mathrm{~mm}$ diameter $\mathrm{V}$-tip gauge (Chatillon force gauge; Lindy Electric, Glen Head, N.Y.) and expressed as mean force in Newtons (N). Electrolyte leakage was determined on three hypodermal mesocarp disks $(10 \mathrm{~mm}$ diameter $\times 1 \mathrm{~mm}$ thick $)$ from three different locations along the fruit equatorial circumference as described previously (Lester and Stein, 1993).

ISOLATION OF PLASMA MEMBRANE VESICLES FOR ANALYSIS OF LIPID, PROTEIN, AND $\mathbf{H}^{+}$-ATPASE ACTIVITY. Plasma membranes were isolated from the equatorial region of hypodermal mesocarp tissues as described previously (Lester and Stein, 1993). Lipids were extracted from plasma membrane pellet preparations and total free sterols and total phospholipids were measured as described previously (Lester and Stein, 1993). Protein content was determined by the method of Bradford (1976). Vanadate sensitive $\mathrm{H}^{+}$-ATPase activity was assayed using procedures of Lester and Stein (1993), and inorganic phosphate was determined as a measure of $\mathrm{H}^{+}$-ATPase activity by the method of Peterson (1978).

LIPOXYGENASE ACTIVITY ASSAY. Lipoxygenase activity in hypodermal mesocarp tissues was determined as reported previously by Lester (1998b). One unit of lipoxygenase activity was equal to 0.001 absorbance units according to Holman (1955). Protein content of the mesocarp extract was determined by the method of Bradford (1976).

Calcium ANd Magnesium anAlyses. A 17-mm-diameter cork borer was used to cut core segments from harvested melons. Cores were taken from the equatorial plane of the fruit. Mineral concentrations were determined on hypodermal mesocarp, middle mesocarp, and inner mesocarp tissue sections cut from the cores. The hypodermal mesocarp section ( $5 \mathrm{~mm}$ thick) was taken from $5 \mathrm{~mm}$ under the epidermis, the inner mesocarp section $(10 \mathrm{~mm}$ thick) was taken from the portion of the mesocarp closest to the seed cavity, and the middle mesocarp section (10 mm thick) was taken from the center of the mesocarp. All sections were weighed immediately to determine fresh weights, and were then dried at 70 ${ }^{\circ} \mathrm{C}$ for $48 \mathrm{~h}$ for dry weight determinations. Tissue sections were wet digested and the digestate resuspended as described in Grusak (1994). Total Ca or Mg content per gram dry weight was determined using atomic absorption spectrophotometry (model 2100; Perkin Elmer, Norwalk, Conn.). In one study, 'Honey Brew' mesocarp tissue was assayed for Ca concentration at 20, 30, 40, 50 (abscission), and $60 \mathrm{~d}$ (abscission plus $10 \mathrm{~d}$ storage at $10^{\circ} \mathrm{C}$ and $90 \% \pm 5 \% \mathrm{RH})$ postanthesis. Calcium and $\mathrm{Mg}$ concentrations also were determined on mesocarp samples taken from fruit at abscission, or following tap water or mineral chelate treatments and postharvest storage.

RADIOLABELED CALCIUM MOVEMENT INTO MESOCARP TISSUES. To assess the short-term movement of $\mathrm{Ca}$ into mesocarp tissues, 'Honey Brew' and 'Explorer' melons (harvested at abscission) were treated with an epidermal application of ${ }^{45} \mathrm{Ca}$-labeled $\mathrm{Ca}$ chelate $\left(0.08\right.$ м Ca-metalosate; specific activity: $9.25 \times 10^{8}$ $\left.\mathrm{Bq} \cdot \mathrm{mol}^{-1}\right)$, and were stored for $24 \mathrm{~h}$ at $5^{\circ} \mathrm{C}$. The Ca-chelate and ${ }^{45} \mathrm{Ca}$ stock solution $\left({ }^{45} \mathrm{CaCl}_{2}\right.$; NEN Life Science Products, Boston, Mass.) were mixed together $24 \mathrm{~h}$ before the initiation of labeling. Radiolabeling was performed by first affixing a plastic collar ( 8 $\mathrm{cm}$ diameter), using softened lanolin paste, to form a well on the surface of each melon. Twenty-five milliliters of ${ }^{45} \mathrm{Ca}$-chelate solution were applied to the well for $20 \mathrm{~min}$ at $22^{\circ} \mathrm{C}$; this solution was removed and the surface gently blotted. Labeled surfaces were allowed to air dry at $22^{\circ} \mathrm{C}$ for $40 \mathrm{~min}$; all fruit were then placed in a $5^{\circ} \mathrm{C}$ cold room. Twenty-four hours after the initiation of labeling, a 7-mm-diameter cork borer was used to remove radial samples from the central portion of each labeled region. These were cut into the following segments: epidermis, hypodermal mesocarp, first centimeter of middle mesocarp, second centimeter of middle mesocarp, and the remaining middle to inner mesocarp (not including seeds). All segments were placed in scintillation vials with $0.5 \mathrm{~mL} 95 \%$ ethanol plus $0.5 \mathrm{~mL} 0.5 \%$ (w/v) sodium hypochlorite, and stored for $24 \mathrm{~h}$. Ten milliliters of BCS liquid scintillation cocktail (Amersham Corp., Arlington Heights, Ill.) were added to each vial and radioactivity was determined $24 \mathrm{~h}$ later by coincidence counting using a liquid scintillation counter (model LS 5000TD; Beckman Instruments, Fullerton, Calif.). All sample counts were corrected for background counts and quenching. Data are presented for each segment as the percent of ${ }^{45} \mathrm{Ca}$ measured in the total core sample (i.e., ${ }^{45} \mathrm{Ca}$ adsorbed on the epidermal surface and absorbed into the core sample).

Histology. Epidermal and hypodermal mesocarp tissue segments $(10 \times 5 \times 2 \mathrm{~mm})$ taken from the fruit equatorial region were fixed for at least $48 \mathrm{~h}$ in 1 formalin : 1 acetic acid : 18 alcohol (by volume) under a slight vacuum. After fixation, the segments were dehydrated in a tertiary butyl alcohol series, embedded in Paraplast (Oxford Labware, St. Louis, Mo.) (melting point 56 to $57^{\circ} \mathrm{C}$ ), sectioned serially on a rotary microtome at $12 \mu \mathrm{m}$ thickness, affixed to slides using Haupt's adhesive, then infiltrated and stained with safranin and fast green, (Johanson, 1940). Photomicrographs were generated using a photomicroscope (Axioplan; Carl Zeiss Inc., Thornwood, N.Y.) equipped with an attached 35 mm camera.

STATiSTICS. Analysis of variance was used to evaluate treatment differences for physicochemical and ion content data (SAS Inst., Cary, N.C.). Duncan's multiple range test $(P \leq 0.05)$ was used to discern between treatment classifications when $F$ values were significant for main effects. Data are expressed as the average of five, single-fruit replications per cultivar per treatment. 
Table 1. Calcium concentration of 'Honey Brew' honeydew mesocarp tissues 20 to $60 \mathrm{~d}$ after anthesis.

\begin{tabular}{|c|c|c|c|}
\hline \multirow{2}{*}{$\begin{array}{l}\text { Days after } \\
\text { anthesis }\end{array}$} & \multicolumn{3}{|c|}{ Mesocarp } \\
\hline & Hypodermal & Middle & Inner \\
\hline & \multicolumn{3}{|c|}{ Ca (mg·g ${ }^{-1}$ dry wt) } \\
\hline 20 & $3.09 \pm 0.27$ & $2.38 \pm 0.12$ & $2.73 \pm 0.12$ \\
\hline 30 & $4.60 \pm 0.30$ & $1.58 \pm 0.30$ & $1.10 \pm 0.11$ \\
\hline 40 & $3.99 \pm 0.36$ & $0.29 \pm 0.02$ & $0.19 \pm 0.01$ \\
\hline 50 & $3.88 \pm 0.22$ & $0.14 \pm 0.01$ & $0.14 \pm 0.01$ \\
\hline $60^{z}$ & $2.65 \pm 0.27$ & $0.20 \pm 0.02$ & $0.17 \pm 0.01$ \\
\hline
\end{tabular}

$\overline{\mathrm{z}}$ Sixty-day postanthesis fruit were abscised at $50 \mathrm{~d}$, and then were stored $7 \mathrm{~d}$ at $10{ }^{\circ} \mathrm{C}$ plus $3 \mathrm{~d}$ at $21{ }^{\circ} \mathrm{C}$. Data are expressed as means \pm sD of 10 replications.

\section{Results and Discussion}

Calcium Profile study. To develop a baseline of Ca accumulation in 'Honey Brew' honeydew, the Ca concentration was measured as fruit developed. Calcium concentration in middle and inner mesocarp tissues were similar on either a dry weight basis (Table 1) or a fresh weight basis (data not shown). Middle and inner mesocarp tissue $\mathrm{Ca}$ concentration was highest $20 \mathrm{~d}$ after anthesis (DAA), declined with age until 50 DAA, then increased slightly by 60 DAA. Hypodermal mesocarp Ca concentration showed the opposite trend in that it increased from 20 DAA to 50 DAA (abscission), then declined by 60 DAA. These mesocarp Ca concentration profiles in 'Honey Brew' are similar to those previously reported for netted muskmelons (Bernadac et al., 1996). 'Honey Brew' (Table 1) and netted muskmelon (Bernadac et al., 1996) hypodermal mesocarp tissue Ca concentration increased during fruit growth, peaked at fruit maturation, and then declined during postharvest storage. It is this postharvest decline in melon hypodermal mesocarp tissue that is of concern, because as previously reported (Lester, 1996), senescence can be retarded if postharvest muskmelon hypodermal mesocarp tissue $\mathrm{Ca}$ concentration can be maintained at an elevated level.

Postharvest mineral chelate application. At abscission (harvest), 'Honey Brew' and 'Explorer' hypodermal mesocarp tissue $\mathrm{Ca}$ concentrations were similar and as much as 44-fold higher than those of middle or inner mesocarp tissues (Table 2).
In water-treated fruit, 'Honey Brew' and 'Explorer' hypodermal mesocarp tissue Ca concentration declined $75 \%$ and $36 \%$, respectively, following postharvest storage for $24 \mathrm{~d}$. The middle and inner mesocarp tissue $\mathrm{Ca}$ concentration remained largely unchanged in water-treated fruit, except for the case of 'Explorer' inner mesocarp tissue, which had a 2.7-fold increase.

Treating 'Honey Brew' and 'Explorer' muskmelons with Cachelate or $(\mathrm{Ca}+\mathrm{Mg})$-chelate solutions resulted in higher hypodermal mesocarp Ca concentrations after $10 \mathrm{~d}$ cold storage, relative to fruit treated with water or Mg-chelate solutions (Table 2). At this time, the $\mathrm{Ca}$ concentration in hypodermal mesocarp tissue of fruit treated with $\mathrm{Ca}$-chelate or $(\mathrm{Ca}+\mathrm{Mg})$-chelate was similar to that of fruit analyzed at harvest. Following $10 \mathrm{~d}$ cold storage, 'Honey Brew' hypodermal mesocarp tissue Ca concentration was significantly higher following Ca-chelate and $(\mathrm{Ca}+\mathrm{Mg})-$ chelate treatments, versus $\mathrm{Mg}$-chelate and water treatments, but such was not the case for 'Explorer' fruit. Only the 'Explorer' fruit treated with $(\mathrm{Ca}+\mathrm{Mg})$-chelate had significantly higher hypodermal mesocarp tissue Ca concentration versus all other 'Explorer' postharvest treatments. Following $24 \mathrm{~d}$ storage, hypodermal mesocarp tissue $\mathrm{Ca}$ concentrations were similar across most treatments for 'Honey Brew' and 'Explorer' although a trend toward higher $\mathrm{Ca}$ concentrations was evident for $\mathrm{Ca}$-chelate and $(\mathrm{Ca}+\mathrm{Mg})$-chelate treated fruit.

It is uncertain why the $(\mathrm{Ca}+\mathrm{Mg})$-chelate treatment yielded the highest hypodermal mesocarp Ca concentration for 'Honey Brew' and 'Explorer' fruit, but a possible answer may be that the ion carrier contained a small amount of surfactant (Albion Labs, personal communication). Mason et al. (1974) clearly showed that submerging apple [Malus sylvestris (L.) Mill var. domestica (Borkh.) Mansf. 'Spartan'] in $\mathrm{CaCl}_{2}$ with surfactants increased fruit Ca concentration up to 3 times as compared to $\mathrm{CaCl}_{2}$ alone. In our study, the surfactant concentration of the $(\mathrm{Ca}+\mathrm{Mg})$-chelate solution was 2 -fold higher then that of the individual mineral chelate solutions.

Lack of an effect of the Ca-chelate treatment on hypodermal mesocarp Ca concentration in 'Explorer' fruit may be due to the presence of the epidermal lenticular tissue (netting). It is estimated (data not shown) that as much as $90 \%$ of the epidermis of netted muskmelons is covered with net. Photomicrographs of epidermal sections of netted muskmelon and honeydew fruit demonstrated that the epidermal region above the hypodermal

Table 2. Effect of postharvest application of Ca-chelate or Mg-chelate on Ca concentration of muskmelon mesocarp tissues. Abscissed (harvested) fruit were dipped for $20 \mathrm{~min}$ in water, or a solution containing Ca-chelate $(0.08 \mathrm{M}), \mathrm{Mg}$-chelate $(0.08 \mathrm{M})$, or a combination of each mineral chelate at a total concentration of $0.16 \mathrm{M}[(\mathrm{Ca}+\mathrm{Mg})$-chelate $]$. Control fruit were analyzed at harvest; treated fruit were stored for 7 or $21 \mathrm{~d}$ at $10{ }^{\circ} \mathrm{C}$, plus $3 \mathrm{~d}$ at $21^{\circ} \mathrm{C}$ ('Honey Brew'), or 7 or $21 \mathrm{~d}$ at $4{ }^{\circ} \mathrm{C}$, plus $3 \mathrm{~d}$ at $21^{\circ} \mathrm{C}$ ('Explorer'). Tissue sectioning, processing, and Ca analyses were performed as described in the materials and methods.

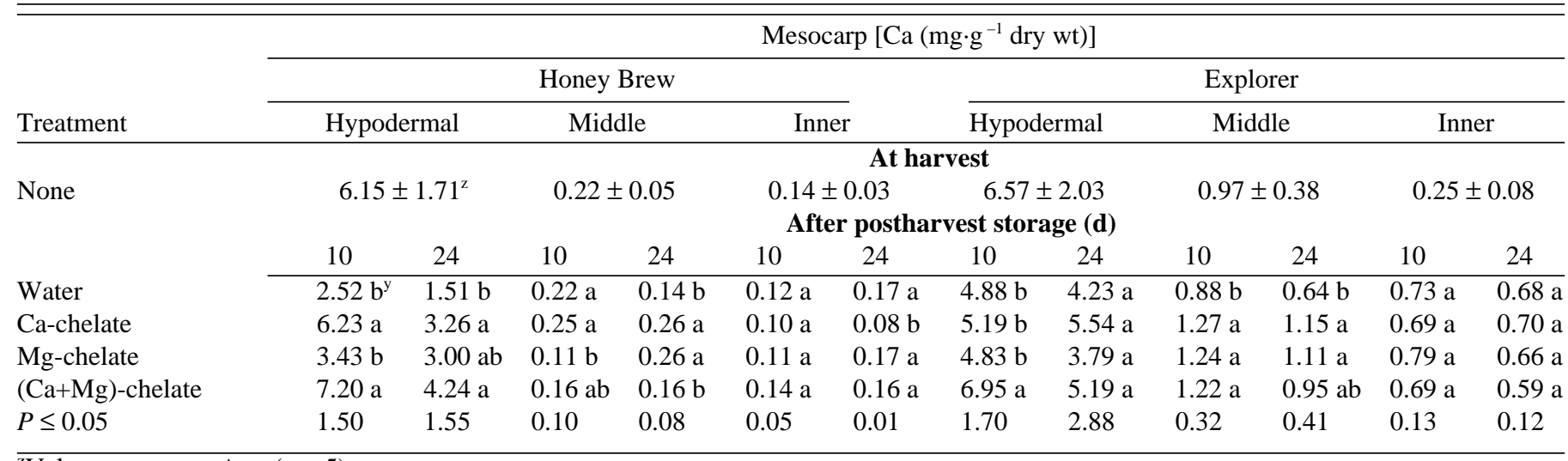

$\overline{\mathrm{z}}$ Values are means \pm SD $(\mathrm{n}=5)$.






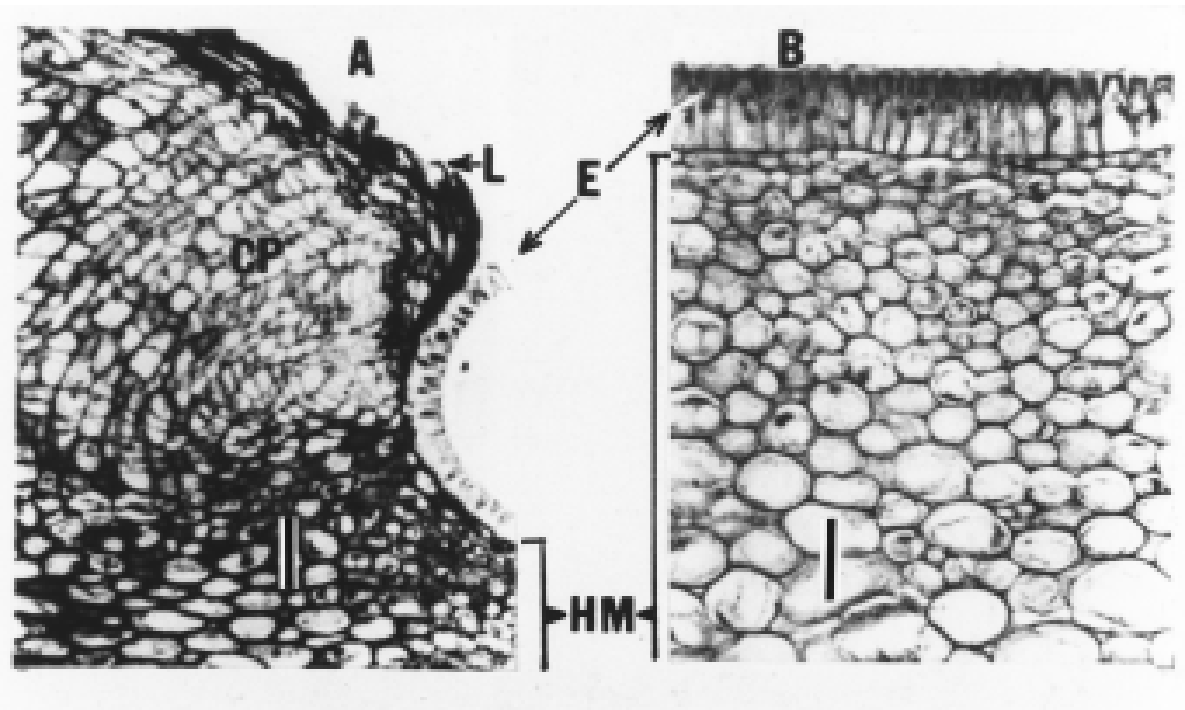

derived from hypodermal mesocarp tissue (Lester, 1988). This netting may sequester $\mathrm{Ca}^{2+}$ and/or the Ca-chelate. To assess the effect of netting on the migration of $\mathrm{Ca}$ chelate, ${ }^{45} \mathrm{Ca}$-labeled chelate was applied to 'Honey Brew' and 'Explorer' epidermal tissues (Table 3). Within $24 \mathrm{~h}$ at $5{ }^{\circ} \mathrm{C}, 23 \%$ of the total labeled $\mathrm{Ca}$ present in the tissues of 'Honey Brew' fruit was measured in mesocarp tissues. However, for fruit regions of 'Explorer' with $100 \%$ netted epidermis, only $9 \%$ of the label was measured in the mesocarp tissues. Similar results were seen for 'Explorer' fruit regions with normal netting ( $\approx 90 \%$ covered), in which $11 \%$ of the label was measured in the mesocarp tissues. These results suggest that netting strongly impedes radial migration of applied Ca-chelate in muskmelons. Higher

Fig. 1. Photomicrographs of longitudinal sections of epidermal and hypodermal tissues from the equatorial regions of (A) 40-d-old abscised netted muskmelons and (B) 50-d-old abscised honeydew melons. $\mathrm{L}=$ lenticel (netting), $\mathrm{E}=$ epidermis, $\mathrm{HM}=$ hypodermal mesocarp, $\mathrm{CP}=$ columnar phelloderm. Scale bars $=1 \mathrm{~mm}$.

mesocarp can be 5-fold thicker than the epidermis of honeydew fruit (Fig. 1). In addition to the net thickness, which created a greater distance for the Ca-chelate to travel to the hypodermal mesocarp, this netting mass is columnar phelloderm which is concentrations of applied $\mathrm{Ca}$-chelate may be needed for increased Ca penetration in netted melons.

Magnesium concentration at harvest was highest in the hypodermal region of the mesocarp in both muskmelon cultivars, but 'Honey Brew' hypodermal mesocarp Mg concentration was more than 2-fold higher that of 'Explorer' (Table 4). However middle mesocarp Mg concentration of 'Explorer' was about 2fold higher than in 'Honey Brew'. 'Honey Brew' and 'Explorer' fruit treated with $\mathrm{Mg}$-chelate or $(\mathrm{Ca}+\mathrm{Mg})$-chelate did not contain

Table 3. Movement of labeled Ca into mesocarp tissues following a 20 -min surface application of ${ }^{45} \mathrm{Ca}$-chelate and storage of whole fruit at $5{ }^{\circ} \mathrm{C}$ for $24 \mathrm{~h}$. Data are presented as a percent of the total ${ }^{45} \mathrm{Ca}$ recovered in muskmelon epidermal and mesocarp regions within a core sample.

\begin{tabular}{|c|c|c|c|c|}
\hline $\begin{array}{l}\text { Mesocarp } \\
\text { tissues }\end{array}$ & $\begin{array}{c}\text { Distance } \\
\text { subepidermal } \\
(\mathrm{mm})\end{array}$ & \multicolumn{3}{|c|}{ Total radioactivity $(\%)$} \\
\hline Hypodermal & $0-2$ & 10.9 & 3.1 & 5.7 \\
\hline Middle & $2-12$ & 8.9 & 3.8 & 3.4 \\
\hline Middle & $12-22$ & 2.5 & 1.4 & 1.0 \\
\hline
\end{tabular}

${ }^{\mathrm{z}}$ Honey Brew melon epidermal tissue was not lenticulated (netted).

${ }^{\mathrm{y}}$ Muskmelon netting covered $100 \%$ of the epidermis.

${ }^{\mathrm{x}}$ Muskmelon netting covered $>90 \%$ of the epidermis.

Table 4. Effect of postharvest application of Ca-chelate or Mg-chelate on Mg concentration of muskmelon mesocarp tissues. Treatments are described in Table 2.



${ }^{\mathrm{z}}$ Values are means $\pm \mathrm{SD}(\mathrm{n}=5)$.

y Mean separation within columns by Duncan's multiple range test, $P \leq 0.05(\mathrm{n}=5)$. 
Table 5. Surface characteristics of muskmelons at harvest or following mineral chelate treatments and storage. See Table 2 for treatment details.

\begin{tabular}{|c|c|c|c|c|c|c|}
\hline \multirow[b]{2}{*}{ Treatment } & \multirow[b]{2}{*}{$\begin{array}{c}\text { Storage } \\
\text { (d) }\end{array}$} & \multicolumn{2}{|c|}{ Surface darkening } & \multicolumn{2}{|c|}{ Diseased areas } & \multirow{2}{*}{$\begin{array}{c}\text { Stem end mold } \\
\text { Fruit } \\
\text { affected } \\
(\%)\end{array}$} \\
\hline & & $\begin{array}{c}\text { Fruit } \\
\text { affected }^{\mathrm{z}} \\
(\%)\end{array}$ & Severity ${ }^{y}$ & $\begin{array}{c}\text { Fruit } \\
\text { affected } \\
(\%)\end{array}$ & $\begin{array}{l}\text { No./ } \\
\text { fruit }\end{array}$ & \\
\hline & \multicolumn{6}{|c|}{ Honey Brew } \\
\hline None & Harvest & 0 & 0 & 0 & 0 & 0 \\
\hline Water & 10 & 20 & 1 & 0 & 0 & 0 \\
\hline Ca-chelate & 10 & 0 & 0 & 0 & 0 & 0 \\
\hline Mg-chelate & 10 & 60 & 3 & 0 & 0 & 0 \\
\hline$(\mathrm{Ca}+\mathrm{Mg})$-chelate & 10 & 20 & 1 & 0 & 0 & 0 \\
\hline Water & 24 & 60 & 5 & 80 & 2 & 0 \\
\hline Ca-chelate & 24 & 0 & 0 & 0 & 0 & 20 \\
\hline Mg-chelate & 24 & 40 & 3 & 40 & 1 & 40 \\
\hline \multirow[t]{2}{*}{$(\mathrm{Ca}+\mathrm{Mg})$-chelate } & 24 & 0 & 0 & 0 & 0 & 0 \\
\hline & \multicolumn{6}{|c|}{ Explorer } \\
\hline None & Harvest & 0 & 0 & 0 & 0 & 0 \\
\hline Water & 10 & 0 & 0 & 0 & 0 & 0 \\
\hline Ca-chelate & 10 & 0 & 0 & 0 & 0 & 20 \\
\hline Mg-chelate & 10 & 0 & 0 & 0 & 0 & 0 \\
\hline$(\mathrm{Ca}+\mathrm{Mg})$-chelate & 10 & 0 & 0 & 0 & 0 & 0 \\
\hline Water & 24 & 60 & 5 & 80 & 3 & 0 \\
\hline Ca-chelate & 24 & 20 & 1 & 80 & 2 & 0 \\
\hline Mg-chelate & 24 & 20 & 1 & 40 & 1 & 0 \\
\hline$(\mathrm{Ca}+\mathrm{Mg})$-chelate & 24 & 0 & 0 & 80 & 2 & 0 \\
\hline
\end{tabular}

$\mathrm{z}(\mathrm{n}=5)$.

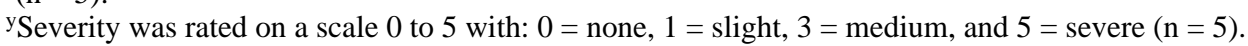

Table 6. Physical characteristics of muskmelons at abscission (harvest) or following mineral chelate treatments and storage. See Table 2 for treatment details.

\begin{tabular}{|c|c|c|c|c|}
\hline Treatment & $\begin{array}{l}\text { Storage } \\
\text { (d) }\end{array}$ & $\begin{array}{l}\text { Firmness } \\
(\mathrm{N})\end{array}$ & $\begin{array}{l}\mathrm{Wt} \\
\text { loss } \\
(\%)\end{array}$ & $\begin{array}{c}\text { Electrolyte } \\
\text { leakage } \\
(\%)^{\mathrm{z}}\end{array}$ \\
\hline & \multicolumn{4}{|c|}{ Honey Brew } \\
\hline None & Harvest & $21.8 \pm 2.8^{\mathrm{y}}$ & 0.0 & $18.5 \pm 2.9$ \\
\hline Water & 10 & $7.0 \mathrm{c}^{\mathrm{x}}$ & $1.9 \mathrm{a}$ & $23.4 \mathrm{a}$ \\
\hline Ca-chelate & 10 & $18.5 \mathrm{a}$ & $1.0 \mathrm{~b}$ & $15.4 \mathrm{~b}$ \\
\hline Mg-chelate & 10 & $14.3 \mathrm{~b}$ & $1.2 \mathrm{~b}$ & $18.2 \mathrm{~b}$ \\
\hline$(\mathrm{Ca}+\mathrm{Mg})$-chelate & 10 & $16.8 \mathrm{ab}$ & $0.8 \mathrm{~b}$ & $17.2 \mathrm{~b}$ \\
\hline$P \leq 0.05$ & & 3.4 & 0.4 & 3.9 \\
\hline Water & 24 & $5.6 \mathrm{~b}$ & $2.6 \mathrm{a}$ & $27.6 \mathrm{ab}$ \\
\hline Ca-chelate & 24 & $13.4 \mathrm{a}$ & $1.7 \mathrm{c}$ & $19.0 \mathrm{c}$ \\
\hline Mg-chelate & 24 & $7.4 \mathrm{a}$ & $2.3 \mathrm{ab}$ & $32.2 \mathrm{a}$ \\
\hline$(\mathrm{Ca}+\mathrm{Mg})$-chelate & 24 & $12.6 \mathrm{a}$ & $1.9 \mathrm{bc}$ & $22.6 \mathrm{bc}$ \\
\hline \multirow[t]{2}{*}{$P \leq 0.05$} & & 3.2 & 0.4 & 5.8 \\
\hline & \multicolumn{4}{|c|}{ Explorer } \\
\hline None & Harvest & $23.7 \pm 2.3$ & 0.0 & $18.5 \pm 2.9$ \\
\hline Water & 10 & $9.1 \mathrm{c}$ & $6.8 \mathrm{a}$ & $31.4 \mathrm{a}$ \\
\hline Ca-chelate & 10 & $9.5 \mathrm{c}$ & $4.0 \mathrm{~b}$ & $26.8 \mathrm{~b}$ \\
\hline Mg-chelate & 10 & 13.7 & b $3.8 \mathrm{~b}$ & $24.0 \mathrm{~b}$ \\
\hline$(\mathrm{Ca}+\mathrm{Mg})$-chelate & 10 & $19.3 \mathrm{a}$ & $3.2 \mathrm{~b}$ & $22.8 \mathrm{~b}$ \\
\hline$P \leq 0.05$ & & 1.8 & 0.8 & 4.1 \\
\hline Water & 24 & $5.8 \mathrm{~b}$ & $8.6 \mathrm{~b}$ & $34.0 \mathrm{a}$ \\
\hline Ca-chelate & 24 & $9.0 \mathrm{a}$ & $8.2 \mathrm{c}$ & $31.6 \mathrm{a}$ \\
\hline Mg-chelate & 24 & $10.4 \mathrm{a}$ & $9.8 \mathrm{a}$ & $31.2 \mathrm{a}$ \\
\hline$(\mathrm{Ca}+\mathrm{Mg})$-chelate & 24 & $10.9 \mathrm{a}$ & $8.0 \mathrm{~b}$ & $29.6 \mathrm{a}$ \\
\hline$P \leq 0.05$ & & 2.2 & 1.1 & 4.5 \\
\hline
\end{tabular}

${ }^{\mathrm{z}}$ Expressed as a percentage of total electrolytes following freezing.

yValues are means \pm SD $(n=5)$.

xMean separation within columns by Duncan's multiple range test, $P \leq 0.05(\mathrm{n}=5)$. 
higher $\mathrm{Mg}$ concentrations in hypodermal mesocarp relative to water-treated fruit (Table 4). Calcium-chelate-treated fruit of 'Honey Brew' showed a significantly lower Mg concentration in the hypodermal mesocarp following $10 \mathrm{~d}$ storage. Tyler and Lorenz (1963) compared Mg concentrations in four different muskmelon types (crenshaw, honeydew, netted muskmelon, and Persian), and found that fruit $\mathrm{Mg}$ concentration changed very little with age.

Surfaces of 'Honey Brew' and 'Explorer' fruit, regardless of treatment, were free of diseases following $10 \mathrm{~d}$ cold storage (Table 5). Surface darkening on 'Explorer' fruit stored $10 \mathrm{~d}$ was nonevident. On Mg-chelate-treated 'Honey Brew', surface darkening was moderate at $10 \mathrm{~d}$ and on all other treated 'Honey Brew' fruit, it was none to slight.

After being stored $24 \mathrm{~d}, 60 \%$ of water-treated fruit of ' $\mathrm{Ex}$ plorer' and 'Honey Brew' had severely darkened surfaces. Only Ca-chelate and $(\mathrm{Ca}+\mathrm{Mg})$-chelate treated 'Honey Brew' and $(\mathrm{Ca}+\mathrm{Mg})$-chelate treated 'Explorer' fruit had no surface darkening at this time. These fruit had higher $\mathrm{Ca}$ concentration in the hypodermal mesocarp $14 \mathrm{~d}$ earlier (Table 2), suggesting that incipient darkening of muskmelon fruit surfaces is associated with a localized, declining $\mathrm{Ca}$ concentration.

A benefit of $\mathrm{Ca}$ and $\mathrm{Ca}+\mathrm{Mg}$ treatments was observed for the physical characteristics of fruit firmness, weight loss, and hypodermal mesocarp electrolyte leakage depending on duration of storage (Table 6). 'Honey Brew' fruit from Ca-chelate and $(\mathrm{Ca}+\mathrm{Mg})$-chelate treatments were the most firm following $10 \mathrm{~d}$ storage, had the lowest moisture loss and the least electrolyte leakage following $24 \mathrm{~d}$ storage, compared to water or $\mathrm{Mg}$-chelate treated fruit. 'Explorer' fruit treated with $(\mathrm{Ca}+\mathrm{Mg})$-chelate also were the most firm ( $10 \mathrm{~d}$ storage), and had the least moisture loss (24 d storage). Peleg et al. (1993) reported that maintaining muskmelon firmness directly promotes longer fruit shelf life. The exact regulation of muskmelon firmness loss is unknown, but is thought to be associated with compositional changes in cell wall fractions (McCollum et al. 1989; Rose et al. 1998).

Our recent and current findings suggest that loss of muskmelon firmness is associated with changes in plasma membrane (PM) integrity as measured by electrolyte leakage, total free sterol to total phospholipid ratio (TFS:TPL), and $\mathrm{H}^{+}$-ATPase activity (Lester and Stein, 1993; Lester and Whitaker, 1996). In our current study, muskmelon hypodermal mesocarp PM integrity was beneficially affected by maintenance of a high tissue $\mathrm{Ca}$ concentration. 'Honey Brew' fruit, from Ca-chelate and $(\mathrm{Ca}+\mathrm{Mg})$ chelate treatments, had the lowest TFS:TPL ratios following 24 d storage, and had the highest $\mathrm{H}^{+}$-ATPase activities at 10 and 24 d storage compared to water or Mg-chelate treated fruit (Tables 7 and 8). 'Explorer' fruit treated with $(\mathrm{Ca}+\mathrm{Mg})$-chelate, versus the other treatments, also had the lowest (TFS:TPL) ratio (10 and $24 \mathrm{~d}$ storage) and the highest total protein content and $\mathrm{H}^{+}$-ATPase activities (10 d storage).

Calcium's beneficial effect on muskmelon hypodermal mesocarp PM integrity may be multifunctional. Calcium is known to regulate the expression and synthesis of proteins and enzymes (Poovaiah and Reddy, 1993), and to reduce catabolism of total phospholipids and delay an increase in TFS:TPL (Picchioni et al., 1996). In muskmelon PM, an increase in TFS:TPL is one of the most obvious changes which occurs during senescence, and is due to catabolism of phospholipids (Lester and Whitaker, 1996). Yermiyahu et al. (1994) described a direct Ca-related benefit to

Table 7. Total free sterol to protein ratio $\left(\mu \mathrm{mol} \cdot \mathrm{mg}^{-1}\right)$, total phospholipid to protein ratio $\left(\mu \mathrm{mol} \cdot \mathrm{mg}^{-1}\right)$ and total free sterol to total phospholipid mol ratio of hypodermal mesocarp plasma membrane fractions of muskmelons at abscission (harvest) or following mineral chelate treatments and storage. See Table 2 for treatment details.

\begin{tabular}{|c|c|c|c|c|}
\hline \multirow[b]{2}{*}{ Treatment } & \multirow[b]{2}{*}{$\begin{array}{l}\text { Storage } \\
\text { (d) }\end{array}$} & \multicolumn{3}{|c|}{ Ratio } \\
\hline & & $\begin{array}{l}\text { Total } \\
\text { free } \\
\text { sterol to } \\
\text { protein }\end{array}$ & $\begin{array}{c}\text { Total } \\
\text { phospholipid } \\
\text { to } \\
\text { protein }\end{array}$ & $\begin{array}{c}\text { Total free } \\
\text { sterol to } \\
\text { total } \\
\text { phospholipid }\end{array}$ \\
\hline & \multicolumn{4}{|c|}{ Honey Brew } \\
\hline None & Harvest & $0.32 \pm 0.04^{z}$ & $0.68 \pm 0.01$ & $0.47^{y}$ \\
\hline Water & 10 & $0.46 \pm 0.04$ & $0.68 \pm 0.03$ & 0.67 \\
\hline Ca-chelate & 10 & $0.44 \pm 0.01$ & $0.65 \pm 0.05$ & 0.68 \\
\hline Mg-chelate & 10 & $0.43 \pm 0.09$ & $0.59 \pm 0.04$ & 0.73 \\
\hline$(\mathrm{Ca}+\mathrm{Mg})$-chelate & 10 & $0.39 \pm 0.05$ & $0.69 \pm 0.04$ & 0.56 \\
\hline Water & 24 & $0.36 \pm 0.04$ & $0.45 \pm 0.06$ & 0.81 \\
\hline Ca-chelate & 24 & $0.40 \pm 0.05$ & $0.57 \pm 0.04$ & 0.71 \\
\hline Mg-chelate & 24 & $040 \pm 0.04$ & $0.44 \pm 0.05$ & 0.81 \\
\hline \multirow[t]{2}{*}{$(\mathrm{Ca}+\mathrm{Mg})$-chelate } & 24 & $0.42 \pm 0.05$ & $0.58 \pm 0.04$ & 0.72 \\
\hline & \multicolumn{4}{|c|}{ Explorer } \\
\hline None & Harvest & $0.35 \pm 0.05$ & $0.98 \pm 0.04$ & 0.36 \\
\hline Water & 10 & $0.30 \pm 0.06$ & $0.34 \pm 0.01$ & 0.85 \\
\hline Ca-chelate & 10 & $0.32 \pm 0.06$ & $0.49 \pm 0.04$ & 0.65 \\
\hline Mg-chelate & 10 & $0.33 \pm 0.03$ & $0.53 \pm 0.03$ & 0.62 \\
\hline$(\mathrm{Ca}+\mathrm{Mg})$-chelate & 10 & $0.28 \pm 0.01$ & $0.57 \pm 0.03$ & 0.49 \\
\hline Water & 24 & $0.25 \pm 0.01$ & $0.28 \pm 0.03$ & 0.89 \\
\hline Ca-chelate & 24 & $0.24 \pm 0.03$ & $0.35 \pm 0.03$ & 0.68 \\
\hline Mg-chelate & 24 & $0.29 \pm 0.06$ & $0.39 \pm 0.03$ & 0.74 \\
\hline$(\mathrm{Ca}+\mathrm{Mg})$-chelate & 24 & $0.26 \pm 0.02$ & $0.40 \pm 0.02$ & 0.65 \\
\hline
\end{tabular}

${ }^{\mathrm{Z}}$ Values are means \pm SD $(n=5)$.

${ }^{\mathrm{y}}$ Values are (mean total free sterol : protein ratio) : (mean total phospholipid : protein ratio) ratios. 
Table 8. Total and specific $\mathrm{H}^{+}$-ATPase activity, and protein content of hypodermal mesocarp plasma membrane and lipoxygenase (LOX) activity of the hypodermal mesocarp tissue of muskmelons at abscission (harvest) or following mineral chelate treatments and storage. See Table 2 for treatment details.

\begin{tabular}{|c|c|c|c|c|c|}
\hline Treatment & $\begin{array}{l}\text { Storage } \\
\text { (d) }\end{array}$ & $\begin{array}{c}\text { Total } \mathrm{H}^{+}- \\
\text {ATPase activity } \\
{\left[\mathrm{Pi}\left(\mu \mathrm{mol} \cdot \mathrm{h}^{-1}\right)\right]}\end{array}$ & $\begin{array}{c}\text { Specific } \mathrm{H}^{+}- \\
\text {ATPase activity } \\
(\mu \mathrm{mol} \mathrm{Pi} / \\
\text { mg protein/ h) }\end{array}$ & $\begin{array}{l}\text { Total protein } \\
\text { (mg/fraction) }\end{array}$ & $\begin{array}{c}\text { LOX activity } \\
\text { (mg protein/ } \\
\text { fraction) }\end{array}$ \\
\hline & \multicolumn{5}{|c|}{ Honey Brew } \\
\hline None & Harvest & $3.25 \pm 0.30^{\mathrm{z}}$ & $4.92 \pm 0.19$ & $0.66 \pm 0.04$ & $77.6 \pm 2.6$ \\
\hline Water & 10 & $1.90 \mathrm{~d}^{\mathrm{y}}$ & $4.04 \mathrm{c}$ & $0.47 \mathrm{~b}$ & $105.4 \mathrm{a}$ \\
\hline Ca-chelate & 10 & $2.56 \mathrm{~b}$ & $5.11 \mathrm{a}$ & $0.50 \mathrm{ab}$ & $72.2 \mathrm{~b}$ \\
\hline Mg-chelate & 10 & $2.09 \mathrm{c}$ & $4.36 \mathrm{~b}$ & $0.48 \mathrm{~b}$ & $111.0 \mathrm{a}$ \\
\hline$(\mathrm{Ca}+\mathrm{Mg})$-chelate & 10 & $2.68 \mathrm{a}$ & $4.87 \mathrm{a}$ & $0.55 \mathrm{a}$ & $74.5 \mathrm{c}$ \\
\hline$P \leq 0.05$ & & 0.10 & 0.23 & 0.05 & 5.6 \\
\hline Water & 24 & $1.68 \mathrm{c}$ & $3.82 \mathrm{~b}$ & $0.44 \mathrm{~b}$ & $123.5 \mathrm{a}$ \\
\hline Ca-chelate & 24 & $2.28 \mathrm{a}$ & $4.36 \mathrm{a}$ & $0.52 \mathrm{a}$ & $80.1 \mathrm{~b}$ \\
\hline Mg-chelate & 24 & $1.85 \mathrm{~b}$ & $3.87 \mathrm{~b}$ & $0.48 \mathrm{ab}$ & $130.2 \mathrm{a}$ \\
\hline$(\mathrm{Ca}+\mathrm{Mg})$-chelate & 24 & $2.27 \mathrm{a}$ & $4.37 \mathrm{a}$ & $0.52 \mathrm{a}$ & $84.7 \mathrm{~b}$ \\
\hline \multirow[t]{2}{*}{$P \leq 0.05$} & & 0.09 & 0.23 & 0.07 & 7.9 \\
\hline & \multicolumn{5}{|c|}{$\begin{array}{l}0.23 \\
\text { Explorer }\end{array}$} \\
\hline None & Harvest & $3.17 \pm 0.10$ & $7.55 \pm 0.40$ & $0.42 \pm 0.20$ & $68.0 \pm 4.0$ \\
\hline Water & 10 & $2.66 \mathrm{~b}$ & $5.65 \mathrm{~d}$ & $0.47 \mathrm{a}$ & $108.7 \mathrm{a}$ \\
\hline Ca-chelate & 10 & $2.14 \mathrm{~d}$ & $5.94 \mathrm{c}$ & $0.36 \mathrm{~b}$ & $90.0 \mathrm{~b}$ \\
\hline Mg-chelate & 10 & $2.84 \mathrm{a}$ & $6.30 \mathrm{~b}$ & $0.36 \mathrm{~b}$ & $86.1 \mathrm{~b}$ \\
\hline$(\mathrm{Ca}+\mathrm{Mg})$-chelate & 10 & $2.84 \mathrm{a}$ & $6.92 \mathrm{a}$ & $0.41 \mathrm{a}$ & $71.5 \mathrm{c}$ \\
\hline$P \leq 0.05$ & & 0.11 & 0.23 & 0.08 & 7.8 \\
\hline Water & 24 & $1.71 \mathrm{c}$ & $5.04 \mathrm{~b}$ & $0.34 \mathrm{a}$ & $125.2 \mathrm{a}$ \\
\hline Ca-chelate & 24 & $1.80 \mathrm{~b}$ & $5.45 \mathrm{a}$ & $0.33 \mathrm{a}$ & $97.1 \mathrm{c}$ \\
\hline Mg-chelate & 24 & $1.82 \mathrm{~b}$ & $5.50 \mathrm{a}$ & $0.33 \mathrm{a}$ & $106.2 \mathrm{~b}$ \\
\hline$(\mathrm{Ca}+\mathrm{Mg})$-chelate & 24 & $2.01 \mathrm{a}$ & $5.30 \mathrm{a}$ & $0.38 \mathrm{a}$ & $89.7 \mathrm{~d}$ \\
\hline$P \leq 0.05$ & & 0.09 & 0.20 & 0.09 & 7.8 \\
\hline
\end{tabular}

ZValues are means \pm SD $(n=5)$.

'Mean separation within columns by Duncan's multiple range test, $P \leq 0.05(\mathrm{n}=5)$.

muskmelon root PM phospholipids relative to $\mathrm{Mg}$, by demonstrating that $\mathrm{Ca}$ serves as a specific electrostatic binder on the head group of negatively charged phospholipids, and that the phospholipid binding constant of $\mathrm{Ca}$ is 5.6-fold greater than that of $\mathrm{Mg}$, thereby directly regulating melon PM permeability (i.e., integrity). Kinoshita et al. (1995) showed that cellular Ca concentration directly regulates $\mathrm{PM} \mathrm{H}^{+}$-ATPase activity. In our study, muskmelons with elevated hypodermal mesocarp Ca concentration had lower TFS:TPL ratios and subsequently higher total protein content and $\mathrm{H}^{+}$-ATPase activity, which positively affected PM integrity.

An additional senescence-related assault on muskmelon PM integrity is lipid peroxidation by lipoxygenase (LOX). In netted and honeydew PM, lipid degradation via LOX activity is greatest in mature and postharvest fruit (Lacan and Baccou, 1998; Lester, 1990, 1998b). Ferguson (1984) reported that Ca directly influences membrane lipid peroxidation by lowering the concentration of free radicals. LOX activity (Table 8) was lower in fruit which had experienced the greatest $\mathrm{Ca}$ enrichment in hypodermal mesocarp tissues ( $\mathrm{Ca}$ in 'Honey Brew' and $\mathrm{Ca}+\mathrm{Mg}$ in 'Explorer' and 'Honey Brew'). This may have resulted from $\mathrm{Ca}$ indirectly interacting with LOX activity by disrupting free radical production, or by serving as a membrane protective barrier to disrupt lipid peroxidation by free radicals (Clarkson, 1984).

In summary, this study demonstrated that Ca concentration in muskmelon hypodermal mesocarp tissue is highest before abscission. Following $24 \mathrm{~d}$ postharvest storage, Ca concentration within the hypodermal mesocarp dropped $36 \%$ to $75 \%$, depending on muskmelon cultivar, and this loss in $\mathrm{Ca}$ was associated with heightened senescence as measured by surface darkening, diseased areas, decreased firmness, increased weight loss, and PM perturbation. The decline in the Ca concentration in the hypodermal mesocarp after harvest is due to Ca diffusing into the middle and inner layers of fruit and most likely repositing in the seeds. Treating fully abscised, greenhouse-grown, hybrid honeydew muskmelons with 0.08 m chelated Ca effectively maintained $\mathrm{Ca}$ concentration in the hypodermal mesocarp tissue at a level that extended postharvest storage. Inclusion of Ca-chelate dips with existing field harvesting operations could have a significant economic impact on the melon industry, by enabling shipment of high quality melons over greater distances, and thus to more markets. Additionally, new markets could be developed for very sweet, highly nutritious, vine ripened (abscised) honeydew fruit which, at present, have a limited postharvest storage life.

\section{Literature Cited}

Anderson, J.L. and W.F. Campbell. 1995. Calcium transport and ATPase activity in microsomal vesicle fraction from 'Montmorency' sour cherry fruit. Acta Hort. 398:47-57.

Bernadac, A., I. Jean-Baptiste, G. Bertoni, and P. Morard. 1996. Changes in calcium contents during melon (Cucumis melo L.) fruit development. Scientia Hort. 66:181-189.

Bradford, M.M. 1976. A rapid and sensitive method for the quantitation of microgram quantities of protein utilizing the principle of protein dye binding. Anal. Biochem. 72:248-254.

Carter, W.W. 1981. Postharvest treatment for control of stem-scar, rind, 
and decay fungi of cantaloupe. Plant Dis. 65:815-816.

Clarkson, D.T. 1984. Calcium transport between tissues and its distribution in the plant. Plant Cell Environ. 7:449-456.

Ferguson, I.B. 1984. Calcium in plant senescence and fruit ripening. Plant, Cell Environ. 7:477-489.

Garcia, J.M., S. Herrera, and A. Morilla. 1996. Effects of postharvest dips in calcium chloride on strawberry. J. Agr. Food Chem. 44:30-33.

Gerasopoulos, D., V. Chouliaras, and S. Lionakis. 1996. Effects of preharvest calcium chloride sprays on maturity and storability of 'Hayward' kiwifruit. Postharvest Biol. Technol. 7:65-72.

Grusak, M.A. 1994. Iron transport to developing ovules of Pisum sativum. I. Seed import characteristics and phloem iron-loading capacity of source regions. Plant Physiol. 104:649-655.

Holman, R.T. 1955. Measurement of lipoxidase activity. Methods Biochem. Anal. 2:113.

Johanson, A.D. 1940. Plant microtechnique. McGraw-Hill, New York.

Kinoshita, T., M. Nishimura, and K. Shimazaki. 1995. Cytosolic concentration of $\mathrm{Ca}^{2+}$ regulates the plasma membrane $\mathrm{H}^{+}$ATPase in guard cells of fava bean. Plant Cell 7:1333-1342.

Lacan, D. and J. C. Baccou. 1998. High levels of antioxidant enzymes correlate with delayed senescence in nonnetted muskmelon fruits. Planta 204:377-382.

Lester, G. 1988. Comparisons of 'Honeydew' and netted muskmelon fruit tissues in relation to storage life. HortScience 23:180-182.

Lester, G. 1989. Gamma irradiation, hot water and imazalil treatments on decay organisms and physical quality of stored netted muskmelon fruit. J. Food Safety 10:21-30.

Lester, G. 1990. Lipoxygenase activity of hypodermal- and middlemesocarp tissues from netted muskmelon fruit during maturation and storage. J. Amer. Soc. Hort. Sci. 115:612-615.

Lester, G. 1996. Calcium alters senescence rate of postharvest muskmelon fruit disks. Postharvest Biol. Technol. 7:91-96.

Lester, G. 1998a. Diurnal growth measurements of honeydew and muskmelon fruits. HortScience 33:156.

Lester, G.E. 1998b. Physicochemical characterization of hybrid honeydew muskmelon fruit (Cucumis melo L. var. inodorus Naud.) following maturation, abscission, and postharvest storage. J. Amer. Soc. Hort. Sci. 123:126-129.

Lester, G. and E. Stein. 1993. Plasma membrane physicochemical changes during maturation and postharvest storage of muskmelon fruit. J. Amer. Soc. Hort. Sci. 118:223-227.

Lester, G. and B.D. Whitaker. 1996. Gamma-ray-induced changes in hypodermal mesocarp tissue plasma membrane of pre- and poststorage muskmelon. Physiol. Plant. 98:265-270.

Mason, J.L., J.M. McDougald, and B.G. Drought. 1974. Calcium concentration in apple fruit resulting from calcium chloride dips modified by surfactants and thickeners. HortScience 9:122-123.

McCollum, T.G., D.J. Huber, and D.J. Cantliffe. 1989. Modification of polyuronides and hemicelluloses during muskmelon fruit softening. Physiol. Plant. 76:303-308.

Miklus, M.B. and R.B. Beelman. 1996. $\mathrm{CaCl}_{2}$ treated irrigation water applied to mushroom crops (Agaricus bisporus) increases Ca concentration and improves postharvest quality and shelf life. Mycologia 88:403-409.

Peleg, K., Y. Aharoni, A. Copel, and M. Gil. 1993. Non-destructive method for measurement of melon firmness during storage and shelflife. Intl. Agrophys. 7:265-272.

Peterson, G.L. 1978. A simplified method for analysis of inorganic phosphate in the presence of interfering substances. Anal. Biochem. 84:164-172.

Picchioni, G.A., A.E. Watada, B.D. Whitaker, and A. Reyes. 1996. Calcium delays senescence-related membrane lipid changes and increases net synthesis of membrane lipid components in shredded carrots. Postharvest Biol. Technol. 9:235-245.

Poovaiah, B.W., G.M. Glenn, and A.S.N. Reddy. 1988. Calcium and fruit softening: Physiology and biochemistry. Hort. Rev. 10:107-153.

Poovaiah, B.W. and A.S.N. Reddy. 1993. Calcium and signal transduction in plants. Crit. Rev. Plant Sci. 12:185-211.

Rose, J.K.C., K.A. Hadfield, J.M. Labavitch, and A.B. Bennett. 1998. Temporal sequence of cell wall disassembly in rapidly ripening melon fruit. Plant Physiol. 117:345-361.

Scott, W.D., B.D. McCraw, J.E. Motes, and M.W. Smith. 1993. Application of calcium to soil and cultivar affect elemental concentration of watermelon leaf and rind tissue. J. Amer. Soc. Hort. Sci. 118:201-206.

Tyler, K.B. and O.A. Lorenz. 1963. Nutrient absorption and growth of four muskmelon varieties. J. Amer. Soc. Hort. Sci. 84:364-371.

Yermiyahu, U., S. Nir, G. Ben-Hayyin, and U. Kafkafi. 1994. Quantitative competition of calcium with sodium or magnesium for sorption sites on plasma membrane vesicles of melon (Cucumis melo L.) root cells. J. Membrane Biol. 138:55-63. 